\title{
Simple isatin derivatives as free radical scavengers: Synthesis, biological evaluation and structure-activity relationship
}

\author{
Gang Chen ${ }^{1}$, Ye Wang ${ }^{2}$ Xiaojiang $\mathrm{Hao}^{2 *}$, Shuzhen $\mathrm{Mu}^{2}$ and Qianyun Sun ${ }^{2}$
}

\begin{abstract}
To develop more potent small molecules with enhanced free radical scavenger properties, a series of $\mathrm{N}$-substituted isatin derivatives was synthesized, and the cytoprotective effect on the apoptosis of PC12 cells induced by $\mathrm{H}_{2} \mathrm{O}_{2}$ was screened. All these compounds were found to be active, and $\mathrm{N}$-ethyl isatin was found with the most potent activity of $69.7 \%$ protective effect on PC12 cells. Structure-activity relationship analyses showed the bioactivity of $\mathrm{N}$ alkyl isatins decline as the increasing of the chain of the alkyl group, furthermore odd-even effect was found in the activity, which is interesting for further investigation.
\end{abstract}

\section{Background}

Oxidative stress has been implicated as a major role in the onset and progression of a vast variety of clinical abnormalities including neurodegenerative disorders. Free radicals play important roles in many physiological and pathological conditions [1]. In general, the generation and scavenging of oxygen free radicals is balanced and any imbalance or excessive amounts of active radicals may contribute to disease development. It has been found that free radical reactions can produce deleterious modifications in membranes, proteins, enzymes, and DNA [2], increasing the risk of diseases such as cancer [3], Alzheimer's [4], Parkinson's [5], angiocardiopathy [6], arthritis [7], asthma [8], diabetes [9], and degenerative eye disease [10]. Therefore, it is important to find effective scavengers of free radicals for prevention and treatment of such disorders.

Isatin is an endogenous indole present in mammalian tissues and fluids [11]. The substance was initially discovered as a component of endogenous monoamine oxidase (MAO) inhibitory activity, tribulin, and subsequently identified as a selective inhibitor of MAO $B$ [12]. Further investigations have shown that isatin acts as an antagonist of both atrial natriuretic peptidestimulated and nitric oxide-stimulated guanylate cyclase

\footnotetext{
* Correspondence: haoxj@mail.kib.ac.cn

${ }^{2}$ Key Laboratory of Chemistry for Natural Products of Guizhou Province and Chinese Academy of Sciences, Guiyang 550002, PR China

Full list of author information is available at the end of the article
}

activity [13-15]. Isatin has a distinct and discontinuous distribution in rat brain and other tissues; the highest concentrations in the brain are found in the hippocampus and cerebellum [10]. Many Isatin derivatives, such as isatin hydrazono, isatin Mannich bases, isatin based spiroazetidinones and 3-(methylene)indolin-2-ones, have also been reported to possess neuroprotection activity [16-19].

To develop more potent small molecules with enhanced free radical scavenger properties, a series of $N$-substituted isatin derivatives was synthesized by substitution reactions (as shown in Scheme 1), and the cytoprotective effect on the apoptosis of PC12 cells induced by $\mathrm{H}_{2} \mathrm{O}_{2}$ was screened.

\section{Results and Discussion Chemistry}

The $N$-substituted isatin derivatives were synthesized by reactions of substitution reaction. The reaction between isatin and halohydrocarbon has been reported being carried out in the presence of $\mathrm{NaOEt}$ using EtOH as solvent or in the presence of $\mathrm{NaH}$ using DMF as solvent [16]. The reactants and the solvents involved in the reactions must be anhydrous. To develop a simple method to synthesize $\mathrm{N}$-substituted isatin derivatives, we firstly screened the effect of the base and solvent on the yield of the reaction of isatin and bromoethane $\left(\mathrm{C}_{2} \mathrm{H}_{5} \mathrm{Br}\right)$, and the results was shown in Table 1 . 


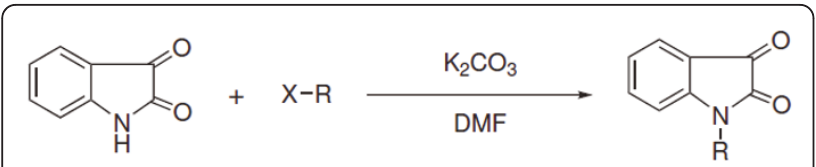

Scheme 1 Synthesis of $\mathbf{N}$-substituted isatin derivatives.

In this reaction, the protons transfers from $\mathrm{N}-\mathrm{H}$ (a Brösted acid) to a Brösted or Lewis base via the hydrogen-bonded covalent and ionic complexes [20], producing the isatin anion which is the nucleophilic reactant to the halohydrocarbon. Higher solvent polarity can promote the proton-transfer equilibrium and leads to the higher yield [20]. From this table, it can be found that $\mathrm{K}_{2} \mathrm{CO}_{3}$-DMF system was an effective promotion for this reaction and other base-solvent systems were not effective with the yield no more than $60 \%$. The possible reason might be that weak base can not help the proton transfer at the beginning effectively, but the too strong bases will lead to the substitution reaction between bromoethane and $\mathrm{OH}^{-}$. DMF exhibits the highest yield of $89 \%$ with $\mathrm{K}_{2} \mathrm{CO}_{3}$ for its highest solvent polarity, so the $\mathrm{K}_{2} \mathrm{CO}_{3}$-DMF was selected as the reactant reaction system in the following synthesis, and the results were shown in Table 2.

\section{Bioactivity}

The chemical modification of lead compound $\mathbf{1}$, focusing on the $\mathrm{N}$-substituent, was carried out to further improve the free scavenging ability. A series of new $N$ substituted isatin derivatives (compounds 2-12) was synthesized. The free radical scavenging properties of these derivatives were evaluated to elucidate structureactivity relationships. The protective effect on the apoptosis of $\mathrm{PC} 12$ cells induced by $\mathrm{H}_{2} \mathrm{O}_{2}$ by free radical scavenging of these compounds against $\mathrm{H}_{2} \mathrm{O}_{2}$ were evaluated by cell survival assay in PC12 cells using a reported method [21]. The results were given in Table 3.

From the table, we can find almost all of the compounds showed potent activity at the condensation of 2

Table 1 The substitution reaction between isatin and bromoethane

\begin{tabular}{ccccc}
\hline No. & Solvent & Base & Time (h) & Yield (\%) \\
\hline 1 & DMF & $\mathrm{Na}_{2} \mathrm{CO}_{3}$ & 24 & 33 \\
2 & $\mathrm{DMF}$ & $\mathrm{K}_{2} \mathrm{CO}_{3}$ & 12 & 89 \\
3 & $\mathrm{DMF}$ & $\mathrm{NaOH}$ & 12 & 40 \\
4 & $\mathrm{DMF}$ & $\mathrm{KOH}$ & 12 & 41 \\
5 & $\mathrm{DMF}$ & $\mathrm{TEA}$ & 24 & 60 \\
6 & $\mathrm{MeOH}$ & $\mathrm{K}_{2} \mathrm{CO}_{3}$ & 24 & 12 \\
7 & $\mathrm{THF}$ & $\mathrm{K}_{2} \mathrm{CO}_{3}$ & 24 & 25 \\
8 & $\mathrm{DCM}$ & $\mathrm{K}_{2} \mathrm{CO}_{3}$ & 24 & 19 \\
9 & Acetonitrile & $\mathrm{K}_{2} \mathrm{CO}_{3}$ & 24 & 15 \\
\hline
\end{tabular}

Table 2 Synthesis of $\mathbf{N}$-substituted isatin derivatives

\begin{tabular}{cccc}
\hline Compound & $\mathbf{R}$ & Time (h) & Yield (\%) \\
\hline $\mathbf{1}$ & $\mathrm{H}$ & - & - \\
$\mathbf{2}$ & $\mathrm{CH}_{3}$ & 4 & 87 \\
$\mathbf{3}$ & $\mathrm{C}_{2} \mathrm{H}_{5}$ & 12 & 89 \\
$\mathbf{4}$ & $\left(\mathrm{CH}_{2}\right)_{2} \mathrm{CH}_{3}$ & 12 & 89 \\
$\mathbf{5}$ & $\left(\mathrm{CH}_{2}\right)_{3} \mathrm{CH}_{3}$ & 24 & 93 \\
$\mathbf{6}$ & $\left(\mathrm{CH}_{2}\right)_{4} \mathrm{CH}_{3}$ & 24 & 90 \\
$\mathbf{7}$ & $\left(\mathrm{CH}_{2}\right)_{5} \mathrm{CH}_{3}$ & 24 & 95 \\
$\mathbf{8}$ & $\mathrm{CH}_{2} \mathrm{CH}_{2} \mathrm{CH}_{2}$ & 12 & 93 \\
$\mathbf{9}$ & $\mathrm{CH}_{2} \mathrm{C}_{6} \mathrm{H}_{5}$ & 12 & 90 \\
$\mathbf{1 0}$ & $\mathrm{CH}_{2} \mathrm{COOC}_{2} \mathrm{H}_{5}$ & 12 & 93 \\
$\mathbf{1 1}$ & $\mathrm{C}_{2} \mathrm{H}_{4} \mathrm{Cl}$ & 24 & 79 \\
$\mathbf{1 2}$ & $\mathrm{C}_{2} \mathrm{H}_{4} \mathrm{Br}$ & 24 & 83 \\
\hline
\end{tabular}

$\mu \mathrm{g} / \mathrm{ml}$, which were more effective than VE $(( \pm) \alpha$-Tocophreol with the percentage of $22.5 \%)$. There is a noteworthy phenomenon that the activities of all compounds at the condensation of $2 \mu \mathrm{g} / \mathrm{ml}$ are more potent than that at the condensation of $20 \mu \mathrm{g} / \mathrm{ml}$, and the mechanism will be interesting for the further investigation. Compound $\mathbf{3}$ and $\mathbf{8}$ exhibited the most potent activity with the protective effect of $69.8 \%$ and $69.5 \%$ at the condensation of $2 \mu \mathrm{g} / \mathrm{ml}$ respectively, which are more potent than that at the condensation of $20 \mu \mathrm{g} / \mathrm{ml}$.

Almost all of these compounds were weakly cytotoxic to PC12 cells at the concentrations of $2-20 \mu \mathrm{g} / \mathrm{ml}$ except compound 11 and 12. Almost all compounds are cytotoxic to PC12 cells at the concentrations of $200 \mu \mathrm{g} / \mathrm{ml}$, the PC12 cells inhibitory effects are more than $40 \%$. Based on the factors, we can conclude the addition of halogenous atom in the substituents (compound $\mathbf{1 1}$ and

Table 3 Inhibitory and protective effects of $\mathbf{N}$-substituted isatin derivatives

\begin{tabular}{|c|c|c|c|c|c|c|}
\hline \multirow[t]{2}{*}{ Compound } & \multicolumn{3}{|c|}{ Inhibitory effect $/ \%^{a}$} & \multicolumn{3}{|c|}{ Protective effect $/ \%^{b}$} \\
\hline & $\begin{array}{c}200 \\
\mu \mathrm{g} / \mathrm{ml}\end{array}$ & $\begin{array}{c}20 \\
\mu \mathrm{g} / \mathrm{ml}\end{array}$ & $\begin{array}{c}2 \\
\mu \mathrm{g} / \mathrm{ml}\end{array}$ & $\begin{array}{c}200 \\
\mu \mathrm{g} / \mathrm{ml}\end{array}$ & $\begin{array}{c}20 \\
\mu \mathrm{g} / \mathrm{ml}\end{array}$ & $\begin{array}{c}2 \\
\mu \mathrm{g} / \mathrm{ml}\end{array}$ \\
\hline 1 & 92.0 & 0.0 & 2.6 & - & 20.1 & 40.4 \\
\hline 2 & 60.6 & 2.7 & 5.0 & - & 31.4 & 50.9 \\
\hline 3 & 45.6 & 0.4 & 7.0 & - & 38.2 & 69.8 \\
\hline 4 & 43.0 & 3.3 & 0.0 & - & 10.1 & 39.7 \\
\hline 5 & 53.3 & 0.0 & 0.0 & - & 30.0 & 60.8 \\
\hline 6 & 51.9 & 0.0 & 0.0 & - & 8.2 & 24.1 \\
\hline 7 & 50.4 & 0.0 & 0.0 & 0 & 15.5 & 20.9 \\
\hline 8 & 54.0 & 2.1 & 0.0 & - & 14.8 & 69.5 \\
\hline 9 & 63.1 & 0.0 & 0.0 & - & 9.3 & 51.3 \\
\hline 10 & 67.9 & 0.0 & 5.3 & - & 46.6 & 54.5 \\
\hline 11 & 63.5 & 20.5 & 5.6 & - & 0 & 25.1 \\
\hline 12 & 61.6 & 24.1 & 12.3 & - & 0 & 62.1 \\
\hline VE & & & 0.0 & & & 22.5 \\
\hline
\end{tabular}

a) Inhibition of PC12 cell growth; $b$ ) protective effect on the apoptosis of PC12 cells induced by $\mathrm{H}_{2} \mathrm{O}_{2}$. 
12) enhance the cytotoxicity at the concentrations of 2$20 \mu \mathrm{g} / \mathrm{ml}$.

The substitution reaction between isatin and halohydrocarbon (C1 to $\mathrm{C} 6)$ gave compounds $2-7$, which provided the appropriate material for the structure-activity relationship analyses. The cytoprotective activities of $N$ substituted isatin derivatives with the alkyl group containing one to six carbon atoms were shown in Figure 1. The activity approximately declines as the increase of the chain of the alkyl group. With a further analysis, it was found that there was a clear odd-even effect in these activities. The activities of $N$-substituted isatin derivatives with odd carbon atoms alkyl group (one, three and five carbon atoms, corresponding compound 2, 4 and 6, marked with solid pillars in Figure 1) decline as the chain of the alkyl group increases, and the same regulation can be found in the activities of the $\mathrm{N}$-substituted isatin derivatives with even carbon atoms alkyl group (two, four and six carbon atoms, corresponding compound 3, 5 and 7, marked with virtual pillars in Figure 1). This regulation exhibits both under the condensation of $2 \mu \mathrm{g} / \mathrm{ml}$ and $20 \mu \mathrm{g} / \mathrm{ml}$, and the activities of $N$ substituted isatin derivatives with even carbon atoms alkyl group are more potent than the that of $\mathrm{N}$-substituted isatin derivatives with parallel odd carbon atoms alkyl group. Besides, by the structure-activity relationship analyses, it was found that the unsaturated bond of the substituent (compound 8-10) can improve the activity compared with the other substituents with similar carbon atoms.

\section{Experimental}

All starting materials and solvents (A.R. grade) were commercially available and were used without further purification. NMR spectra were recorded using a Bruker Drx-400 spectrometer operating at $400 \mathrm{MHz}$ for ${ }^{1} \mathrm{H}$. Mass spectra were recorded on a Micromass Platform spectrometer using a direct-inlet system operating in the electron impact (EI) mode at $75 \mathrm{eV}$. Elemental analyses were obtained using a Carlo Erba 1106 elemental analyzer.

\section{General synthesis of $\mathrm{N}$-alkyl substituted isatin derivatives}

Isatin $(1 \mathrm{mmol})$ and halohydrocarbon $(1.2 \mathrm{mmol})$ were dissolved in DMF $(20 \mathrm{ml})$, and $3 \mathrm{mmol}$ anhydrous $\mathrm{K}_{2} \mathrm{CO}_{3}$ was added. The mixture was stirred under room temperature until the disappearance of isatin, as evidenced by thin-layer chromatography. The solvent was removed in vacuo and the residue was separated by column chromatography (silica gel, petroleum ether/ethyl acetate $=20: 1)$, giving $N$-alkyl substituted isatin compound (compound 2-12).

1-Methylindoline-2,3-dione (Compound 2) ${ }^{1} \mathrm{H}-\mathrm{NMR}$ ( $\mathrm{D}_{6}$-DMSO, $\left.400 \mathrm{MHz}\right): 7.66(1 \mathrm{H}, \mathrm{td}, J=1.2,7.6 \mathrm{~Hz})$, $7.52(1 \mathrm{H}, \mathrm{d}, J=7.6 \mathrm{~Hz}), 7.12(2 \mathrm{H}, \mathrm{t}, J=7.6 \mathrm{~Hz}), 3.12$ $(3 \mathrm{H}, \mathrm{s})$; MS (EI) $\mathrm{m} / z: 161\left(\mathrm{M}^{+}\right)$; Anal. Found: C, 67.01; $\mathrm{H}, 4.40 ; \mathrm{N}, 8.66$ (\%). Calc. for $\left(\mathrm{C}_{9} \mathrm{H}_{7} \mathrm{NO}_{2}\right): \mathrm{C}, 67.07 ; \mathrm{H}$, $4.38 ; \mathrm{N}, 8.69$ (\%).

1-Ethylindoline-2,3-dione (Compound 3) ${ }^{1} \mathrm{H}-\mathrm{NMR}$ $\left(\mathrm{CDCl}_{3}, 400 \mathrm{MHz}\right): 7.57(2 \mathrm{H}, \mathrm{m}), 7.09(1 \mathrm{H}, \mathrm{t}, J=7.6$ $\mathrm{Hz}), 6.89(1 \mathrm{H}, \mathrm{d}, J=7.6 \mathrm{~Hz}), 3.76(2 \mathrm{H}, \mathrm{q}, J=7.6 \mathrm{~Hz})$, $1.29(3 \mathrm{H}, \mathrm{t}, J=7.6 \mathrm{~Hz})$; MS (EI) $m / z: 175\left(\mathrm{M}^{+}\right)$; Anal.

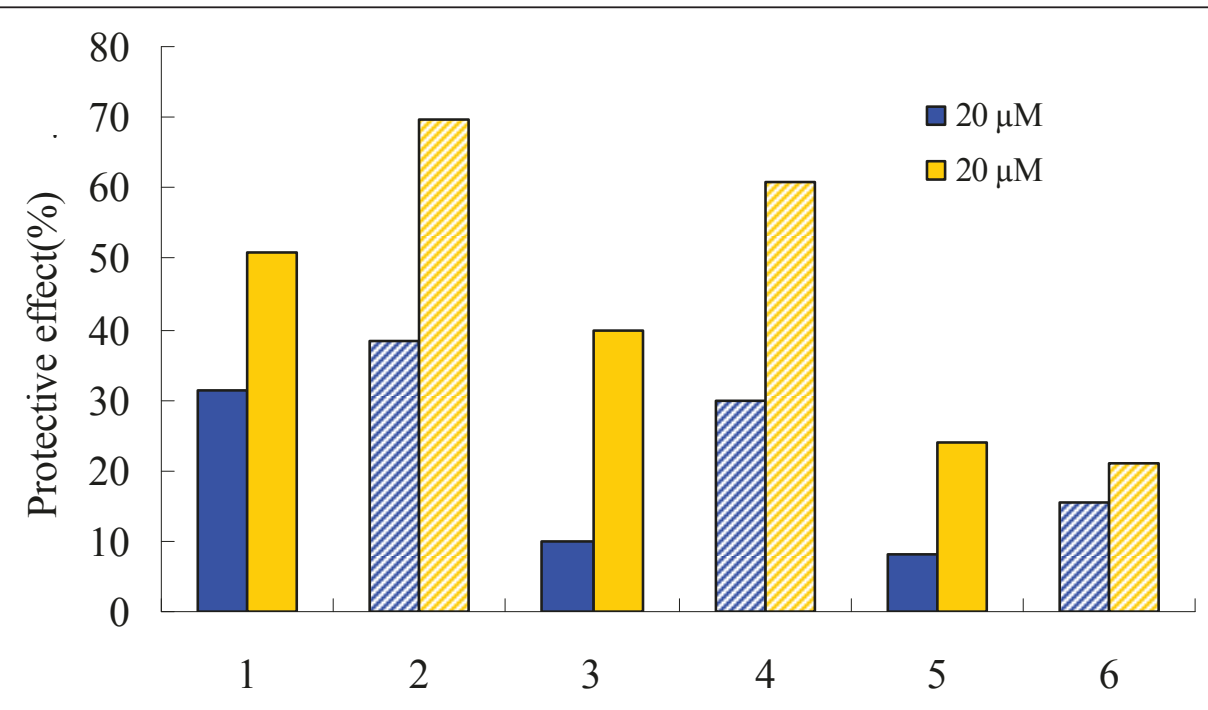

Alkyl-carbon atom amount of the substituent

Figure 1 The cytoprotective activities of $N$-substituted isatin derivatives with the alkyl group containing 1-6 carbon atoms (The corresponding compounds are compounds 2-7.). 
Found: C, 68.59; H, 5.22; N, 8.01 (\%). Calc. for $\left(\mathrm{C}_{10} \mathrm{H}_{9} \mathrm{NO}_{2}\right)$ : C, 68.56; H, 5.18; N, 8.00 (\%).

1-Propylindoline-2,3-dione (Compound 4) ${ }^{1} \mathrm{H}-\mathrm{NMR}$ (D $\mathrm{D}_{6}$-DMSO, $\left.400 \mathrm{MHz}\right): 7.58(1 \mathrm{H}, \mathrm{d}, J=6.8 \mathrm{~Hz}), 7.55(1$ $\mathrm{H}, \mathrm{t}, J=7.6 \mathrm{~Hz}), 7.09(1 \mathrm{H}, \mathrm{t}, J=7.6 \mathrm{~Hz}), 6.88(1 \mathrm{H}, \mathrm{d}, J$ $=8 \mathrm{~Hz}), 3.67(2 \mathrm{H}, \mathrm{t}, J=7.2 \mathrm{~Hz}), 1.72(2 \mathrm{H}, \mathrm{m}, J=7.2-$ $7.6 \mathrm{~Hz}), 0.98(3 \mathrm{H}, \mathrm{t}, J=7.6 \mathrm{~Hz})$; MS (EI) $m / z: 189(\mathrm{M}$ ${ }^{+}$); Anal. Found: C, 69.88; H, 5.89; N, 7.35 (\%). Calc. for $\left(\mathrm{C}_{11} \mathrm{H}_{11} \mathrm{NO}_{2}\right)$ : C, 69.83; H, 5.86; N, 7.40 (\%).

1-Butylindoline-2,3-dione (Compound 5) ${ }^{1} \mathrm{H}-\mathrm{NMR}$ $\left(\mathrm{CDCl}_{3}, 400 \mathrm{MHz}\right) \delta: 7.60(2 \mathrm{H}, \mathrm{m}), 7.12(1 \mathrm{H}, \mathrm{t}, J=7.6$ $\mathrm{Hz}), 6.91(1 \mathrm{H}, \mathrm{d}, J=8.4 \mathrm{~Hz}), 3.73(2 \mathrm{H}, \mathrm{t}, J=7.6 \mathrm{~Hz})$, $1.69(2 \mathrm{H}, \mathrm{m}), 1.42(2 \mathrm{H}, \mathrm{m}), 0.98(3 \mathrm{H}, \mathrm{t}, J=7.2 \mathrm{~Hz})$; MS (EI) $m / z$ : $203\left(\mathrm{M}^{+}\right)$; Anal. Found: C, 70.90; H, 6.59; $\mathrm{N}, 6.90$ (\%). Calc. for $\left(\mathrm{C}_{12} \mathrm{H}_{13} \mathrm{NO}_{2}\right): \mathrm{C}, 70.92 ; \mathrm{H}, 6.54 ; \mathrm{N}$, $6.89(\%)$.

1-Pentylindoline-2,3-dione (Compound 6) ${ }^{1} \mathrm{H}-\mathrm{NMR}$ $\left(\mathrm{CDCl}_{3}, 400 \mathrm{MHz}\right) \delta: 7.60(2 \mathrm{H}, \mathrm{m}), 7.12(1 \mathrm{H}, \mathrm{t}, J=7.6$ $\mathrm{Hz}), 6.91(1 \mathrm{H}, \mathrm{d}, J=8.0 \mathrm{~Hz}), 3.72(2 \mathrm{H}, \mathrm{t}, J=7.6 \mathrm{~Hz})$, $1.71(2 \mathrm{H}, \mathrm{m}), 1.37(4 \mathrm{H}, \mathrm{m}), 0.91(3 \mathrm{H}, \mathrm{t}, J=6.8 \mathrm{~Hz})$; MS (EI) $m / z: 217\left(\mathrm{M}^{+}\right)$; Anal. Found: C, 71.88; H, 7.00; $\mathrm{N}, 6.44$ (\%). Calc. for $\left(\mathrm{C}_{13} \mathrm{H}_{15} \mathrm{NO}_{2}\right): \mathrm{C}, 71.87 ; \mathrm{H}, 6.96 ; \mathrm{N}$, $6.45(\%)$.

1-Hexylindoline-2,3-dione (Compound 7) ${ }^{1} \mathrm{H}-\mathrm{NMR}$ $\left(\mathrm{CDCl}_{3}, 400 \mathrm{MHz}\right) \delta: 7.60(2 \mathrm{H}, \mathrm{m}), 7.11(1 \mathrm{H}, \mathrm{t}, J=7.6$ $\mathrm{Hz}), 6.90(1 \mathrm{H}, \mathrm{d}, J=7.6 \mathrm{~Hz}), 3.72(2 \mathrm{H}, \mathrm{t}, J=7.6 \mathrm{~Hz})$, $1.70(2 \mathrm{H}, \mathrm{m}), 1.31-1.38(6 \mathrm{H}, \mathrm{m}), 0.89(3 \mathrm{H}, \mathrm{t}, J=6.4$ $\mathrm{Hz}$ ); MS (EI) $m / z$ : $231\left(\mathrm{M}^{+}\right)$; Anal. Found: C, 72.72; $\mathrm{H}$, 7.40; N, 6.01 (\%). Calc. for $\left(\mathrm{C}_{14} \mathrm{H}_{17} \mathrm{NO}_{2}\right)$ : C, 72.70; $\mathrm{H}$, $7.41 ; \mathrm{N}, 6.06$ (\%).

1-Allylindoline-2,3-dione (Compound 8) ${ }^{1} \mathrm{H}-\mathrm{NMR}$ (D6-DMSO, $400 \mathrm{MHz}): 7.63(1 \mathrm{H}, \mathrm{t}, J=7.6 \mathrm{~Hz}), 7.55(1$ $\mathrm{H}, \mathrm{d}, J=7.2 \mathrm{~Hz}), 7.12(1 \mathrm{H}, \mathrm{t}, J=7.6 \mathrm{~Hz}), 7.04(1 \mathrm{H}, \mathrm{d}, J$ $=7.6 \mathrm{~Hz}), 5.84(1 \mathrm{H}, \mathrm{m}, J=5.2-5.6 \mathrm{~Hz}), 5.32(1 \mathrm{H}, \mathrm{d}, J=$ $17.2 \mathrm{~Hz}), 5.18(1 \mathrm{H}, \mathrm{d}, J=10.4 \mathrm{~Hz}), 4.30(2 \mathrm{H}, \mathrm{d}, J=4.8$ $\mathrm{Hz}$ ); MS (EI) $m / z$ : $187\left(\mathrm{M}^{+}\right)$; Anal. Found: C, 70.60; H, 4.84; $\mathrm{N}, 7.49$ (\%). Calc. for $\left(\mathrm{C}_{11} \mathrm{H}_{9} \mathrm{NO}_{2}\right)$ : $\mathrm{C}, 70.58 ; \mathrm{H}$, $4.85 ; \mathrm{N}, 7.48$ (\%).

1-Benzylindoline-2,3-dione (Compound 9) ${ }^{1} \mathrm{H}-\mathrm{NMR}$ $\left(\mathrm{D}_{6}\right.$-DMSO, $\left.400 \mathrm{MHz}\right) \delta: 7.56(2 \mathrm{H}, \mathrm{m}), 7.42(2 \mathrm{H}, \mathrm{d}, J$ $=7.6 \mathrm{~Hz}), 7.30(2 \mathrm{H}, \mathrm{t}, J=7.6 \mathrm{~Hz}), 7.27(1 \mathrm{H}, \mathrm{m}), 7.10$ $(1 \mathrm{H}, \mathrm{t}, J=7.6 \mathrm{~Hz}), 6.96(1 \mathrm{H}, \mathrm{m}), 4.90(2 \mathrm{H}, \mathrm{s}) ; \mathrm{MS}(\mathrm{EI})$ $m / z: 233\left(\mathrm{M}^{+}\right)$; Anal. Found: C, 75.99; H, 4.65; N, 5.92 (\%). Calc. for $\left(\mathrm{C}_{15} \mathrm{H}_{11} \mathrm{NO}_{2}\right)$ : C, 75.94; $\mathrm{H}, 4.67 ; \mathrm{N}, 5.90$ (\%).

Ethyl 2-(2,3-dioxoindolin-1-yl)acetate (Compound 10) ${ }^{1} \mathrm{H}-\mathrm{NMR}\left(\mathrm{CDCl}_{3}, 400 \mathrm{MHz}\right) \delta: 7.62(1 \mathrm{H}, \mathrm{d}, J=7.6 \mathrm{~Hz})$, $7.57(1 \mathrm{H}, \mathrm{t}, J=7.6 \mathrm{~Hz}), 7.14(1 \mathrm{H}, \mathrm{t}, J=7.6 \mathrm{~Hz}), 6.77$ $(1 \mathrm{H}, \mathrm{d}, J=7.6 \mathrm{~Hz}), 4.47(2 \mathrm{H}, \mathrm{s}), 4.22(2 \mathrm{H}, \mathrm{q}, J=7.2$ $\mathrm{Hz}), 1.26(3 \mathrm{H}, \mathrm{t}, J=7.2 \mathrm{~Hz})$; MS (EI) $m / z: 233\left(\mathrm{M}^{+}\right)$; Anal. Found: C, 61.84; H, 4.72; N, 6.00 (\%). Calc. for $\left(\mathrm{C}_{12} \mathrm{H}_{11} \mathrm{NO}_{4}\right): \mathrm{C}, 61.80 ; \mathrm{H}, 4.75 ; \mathrm{N}, 6.01$ (\%).

1-(2-Chloroethyl)indoline-2,3-dione (Compound 11) ${ }^{1} \mathrm{H}-\mathrm{NMR}\left(\mathrm{D}_{6}\right.$-DMSO, $\left.400 \mathrm{MHz}\right) \delta: 7.67(1 \mathrm{H}, \mathrm{td}, J=8$,
$1.2 \mathrm{~Hz}), 7.56(1 \mathrm{H}, \mathrm{dd}, J=7.6,1.2 \mathrm{~Hz}), 7.29(1 \mathrm{H}, \mathrm{d}, J=$ $8.0 \mathrm{~Hz}), 7.14(1 \mathrm{H}, \mathrm{dd}, J=7.6,0.8 \mathrm{~Hz}), 4.10(2 \mathrm{H}, \mathrm{t}, J=$ $6.4 \mathrm{~Hz}), 3.70(2 \mathrm{H}, \mathrm{t}, J=6.4 \mathrm{~Hz})$; MS (EI) $m / z: 211(\mathrm{M}$ $\left.{ }^{+}\right)$; Anal. Found: C, 58.86; H, 3.99; N, 13.70 (\%). Calc. for $\left(\mathrm{C}_{10} \mathrm{H}_{8} \mathrm{ClNO}_{2}\right)$ : C, 58.82; H, 3.95; N, $13.72(\%)$. 1-(2-Bromoethyl)indoline-2,3-dione (Compound 12) ${ }^{1} \mathrm{H}-\mathrm{NMR}\left(\mathrm{D}_{6}\right.$-DMSO, $\left.400 \mathrm{MHz}\right) \delta: 7.67(1 \mathrm{H}, \mathrm{td}, J=8$, $1.2 \mathrm{~Hz}), 7.57(1 \mathrm{H}, \mathrm{dd}, J=7.6,1.2 \mathrm{~Hz}), 7.29(1 \mathrm{H}, \mathrm{d}, J=$ $8.0 \mathrm{~Hz}), 7.14(1 \mathrm{H}, \mathrm{dd}, J=7.6,0.8 \mathrm{~Hz}), 4.11(2 \mathrm{H}, \mathrm{t}, J=$ 6.4 Hz), $3.71(2 \mathrm{H}, \mathrm{t}, J=6.4 \mathrm{~Hz})$; MS (EI) $m / z: 254(\mathrm{M}$ $\left.{ }^{+}\right)$; Anal. Found: C, 47.31; H, 3.19; N, 5.50 (\%). Calc. for $\left(\mathrm{C}_{10} \mathrm{H}_{8} \mathrm{BrNO}_{2}\right)$ : C, 47.27; H, 3.17; N, 5.51 (\%).

\section{Acknowledgements}

This work was financially supported by the grant from Scientific Research Program Funded by Shaanxi Provincial Education Department (Program No.11JK0560).

\section{Author details}

${ }^{1}$ College of Chemistry and Chemical Engineering, Xi'an Shiyou University, Xi'an, Shaanxi, 710065, PR China. ${ }^{2}$ Key Laboratory of Chemistry for Natural Products of Guizhou Province and Chinese Academy of Sciences, Guiyang 550002, PR China.

\section{Authors' contributions}

GC has formulated the research idea and prepared the manuscript draft version, YW prepared the manuscript for submission and coordinated further formalities, SM and QS carried out the chemical and biological studies, XH conceived of the study, participated in its design and coordination. All authors have read and approved the final manuscript.

\section{Competing interests}

The authors declare that they have no competing interests.

Received: 19 April 2011 Accepted: 1 July 2011 Published: 1 July 2011

\section{References}

1. Vendemiale G, Grattagliano I, Altomare E: An update on the role of free radicals and antioxidant defense in human disease. Int I Clin Lab Res 1999, 29:49-55.

2. Valko M, Rhodes CJ, Moncol J, Izakovic M, Mazur M: Free radicals, metals and antioxidants in oxidative stress-induced cancer. Chem Biol Interact 2006, 160:1-40.

3. Cooke MS, Evans MD, Dizdaroglu M, Lunec J: Oxidative DNA damage: mechanisms, mutation and disease. FASEB J 2003, 17:1195-1214.

4. Richardson JS: Free radicals in the genesis of Alzheimer's disease. Annals of the New York Academy of Sciences 2006, 695:73-76.

5. Olanow CW: An introduction to the free radical hypothesis in Parkinson's disease. Ann Neurol 1992, 32:52-S9.

6. Bankson DD, Kestin M, Rifai N: Role of free radicals in cancer and atherosclerosis. Clin Lab Med 1993, 13:463-480.

7. Jaswal S, Mehta HC, Sood AK, Kaur J: Antioxidant status in rheumatoid arthritis and role of antioxidant therapy. Clin Chim Acta 2003, 338:123-129.

8. Mak JC, Chan YMM: Reactive oxidant species in asthma. Curr Opin Pulm Med 2006, 12:7-11.

9. Shen SS, Nauduri D, Anders MW: Targeting antioxidants to mitochondria: A new therapeutic direction. Biochim Biophys Acta 2006, 1762:256-265.

10. Glover V, Halket JM, Watkins PJ, Clow A, Goodwin BL, Sandler M: Isatin: Identity with the purified endogenous monoamine oxidase inhibitor tribulin. J Neurochem 1988, 51:656-659.

11. Glover V, Reveley MA, Sandler M: A monoamine oxidase inhibitor in human urine. Biochem Pharmacol 1980, 29:467-470.

12. Medvedev AE, Clow A, Sandler M, Glover V: Isatin: A link between natriuretic peptides and monoamines? Biochem Pharmacol 1996, 52:385-391. 
13. Medvedev AE, Bussygyna O, Pyatakova N, Glover V, Severina I: Effect of isatin on nitric oxide-stimulated soluble guanylate cyclase from human platelets. Biochem Pharmacol 2002, 63:763-766.

14. Glover V, Bhattarya SK, Chakrabarti A, Sandler M: The psychopharmacology of Isatin: A brief review. Stress Med 1998, 14:225-229.

15. Glover V, Medvedev A, Sandler M: Isatin is a potent endogenous antagonist of guanylate cyclase-coupled atrial natriuretic peptide receptors. Life Sci 1995, 57:2073-2079.

16. Webber SE, Tikhe J, Worland ST, Fuhrman SA, Hendrickson TF, Matthews DA, Love RA, Patick AK, Meador JW, Ferre RA, Brown EL, DeLisle DM, Ford CE, Binford SL: Design, synthesis, and evaluation of nonpeptidic inhibitors of human rhinovirus $3 \mathrm{C}$ protease. J Med Chem 1996, 39(26):5072-5082.

17. Chen G, He HP, Ding J, Hao XJ: Synthesis and antitumor activity evaluation of regioselective spiro [pyrrolidine-2, 3'-oxindole] compounds. Heterocycl Commun 2009, 15(5):355-360.

18. Chen G, Wang Y, Gao S, He HP, Li SL, Zhang JX, Ding J, Hao XJ: Synthesis and bioactivity evaluation of 3-hydroxy-3-(phenylethynyl) indol-2-one analogues. J Heterocyclic Chem 2009, 46:217-220.

19. Chen G, Hao XJ, Sun QY, Ding J: Rapid eco-friendly synthesis and bioactivities of 3-nitromethylene-1,3-dihydro-indol-2-one analogues. Chem Pap 2010, 64(5):673-677.

20. Reichardt C: Solvent effects on Brösted acid/base equilibria. Solvent and solvent effect in organic chemistry, third edition Weinheim, FRG: Wiley and Sons; 2003, 647-748.

21. Mosmann TJ: Rapid colorimetric assay for cellular growth and survival: application to proliferation and cytotoxicity assays. J Immunol Methods 1983, 65:55-63.

doi:10.1186/1752-153X-5-37

Cite this article as: Chen et al: Simple isatin derivatives as free radical scavengers: Synthesis, biological evaluation and structure-activity relationship. Chemistry Central Journal 2011 5:37.

Publish with ChemistryCentral and every
scientist can read your work free of charge
"Open access provides opportunities to our
colleagues in other parts of the globe, by allowing
anyone to view the content free of charge."
W. Jeffery Hurst, The Hershey Company.
- available free of charge to the entire scientific community
- peer reviewed and published immediately upon acceptance
- cited in PubMed and archived on PubMed Central
- yours - you keep the copyright
Submit your manuscript here:
http://www.chemistrycentral.com/manuscript/

